\title{
ECONOMIC RESULTS AND DEVELOPMENT OF ORGANIC FARMS IN LATVIA
}

\author{
Armands Veveris ${ }^{1}$, Dr.oec.; Armands Puzulis ${ }^{2}$, Dr.geogr.
}

${ }_{1,2}$ Institute of Agricultural Resources and Economics, Latvia

\begin{abstract}
Organic farming is experiencing rather rapid development in Europe, including in Latvia. This could be rated from different aspects. The purpose of this article is to assess the economic indicators of the development of organic farming, linking them to conclusions stated in various studies in Latvia and other countries on the diverse economic, social and environmental impact of this type of farming, as well as potential problems. So, theoretical and empirical approaches are combined in this article. The different problems we can state as outcome of the research. The farms concentrate in areas with less favourable conditions for conventional farming. Also, large continuous areas under organic farming often leads to low production value per hectare and do not reach social goals.
\end{abstract}

Key words: organic, farms, agriculture, development, effectiveness.

JEL codes: Q15, Q18, Q57.

\section{Introduction}

Organic farming is a different farming paradigm based on the use of local resources and knowledge, contributing to rural development by activating knowledge processes, cooperation, building social capital, creating a rural political environment (Sumane, 2010). It is part of a larger sustainable agriculture that produces healthier food and a better society. Organic farming can be seen as a social movement characterized by networking, solidarity, collective action, shared beliefs.

Organic farming is experiencing rather rapid development in Europe, including in Latvia. This process, however, is not rated unequivocally. In addition, the potential return from the organic farming should be assessed from various aspects - ensuring healthy food, application of environmentfriendly agricultural methods, development of rural areas etc. A complex of these aspects is considered important also in Latvia, thinking about future development of organic farming.

The purpose of this article is to assess the economic indicators of the development of organic farming, linking them to conclusions stated in various studies in Latvia and other countries on the diverse economic, social and environmental impact of this type of farming, as well as potential problems. It is important for the formation of future organic farming policy in the European Union (EU) and Latvia.

The following objectives were set to reach this goal:

- analysis of studies performed in Latvia and abroad on the economic, social, environmental and ethical aspects of organic farming;

- analysis of development of organic farming in the context of Latvia and Baltic States;

- assessment of economic indicators of organic farms in Latvia, including in comparison with the conventional farms.

Qualitative and quantitative economic research methods: analysis and synthesis; comparative analysis, logically and abstractly constructive methods were used in the study, performing analysis of various scientific publications. Novelty of the study must be linked to the used economic indicators, including comparative analysis of farms of various size. The study results may be used in improvement of the Common Agricultural Policy in respect of organic farming.

Scientific studies, official statistics, as well as FADN data is used in the paper. Restrictions of the study are mostly related to the volume of the paper, thus, a limited number of indicators was analysed. 


\section{Research results and discussion}

\section{Theoretical discussion}

Studies on organic farming in Latvia so far point at several problems in development of this type of farming. Regardless of a significant number of farms and size of managed areas, the organic farming in Latvia in general makes a comparatively small contribution in manufacturing of produce (Melece \& Shena, 2019). Development of organic farming in Latvia is affected by several factors indicated in the studies and characteristic to other Eastern European countries. Lack of state policy, requirements for turnover or at least marginal revenue from agriculture, high certification costs, processing and marketing problems, lack of information, bureaucratic problems and restrictions to processing and sale are among them (Melece, 2010). Moreover, small organic farms are excluded from the EU support for cooperatives and manufacturer groups (Melece \&Shena, 2019), affecting development processes and rural well-being.

Nowadays, the concept of rural well-being is not only technical, based on economic data, but also social (Rios et al. 2016). Prosperity in rural contexts is increasingly understood as being multidimensional and that people seek to balance economic parameters with human, social and environmental well-being (Rivera et al., 2017).

Organic farming is increasingly viewed from a sustainability perspective. There is little research on the effects of the environment and climate and their role on organic farming in relation to conventional farming. Studies show lower $\mathrm{CO}_{2}, \mathrm{~N}_{2} \mathrm{O}$, and $\mathrm{CH}_{4}$ emissions, improved soil and water quality, lower energy use per land area, and higher energy efficiency per land area. However, organic farming has lower soil profile SOC stocks, lower crop yields, higher land requirement, lower energy production per land area (Lorenz \& Lal, 2016).

Overall, the organic farming outperforms conventional farming in production, environmental and economic sustainability and welfare components (Reganold \& Wachter, 2016). A meta-analysis, summarizing 40 years of experience and covering 55 crops across continents concludes that by including a price premium, organic farming is more profitable (22 to $35 \%$ higher net cost / value ratios) (20 to $24 \%$ ) if they do not include net present values ( -27 to $-23 \%$ ) - net returns accounting for time value - and benefit / cost ratios ( -8 to $-7 \%$ ) were significantly lower than conventional agriculture. (Crowder \& Reganold, 2015). It is recognized that appropriate investment in agro-ecological studies to improve biological management systems could significantly reduce or eliminate crop differences for some crops or regions (Ponisio et al., 2015).

The effectiveness of organic farming is the subject of debate based on different valuation methodologies; for example, Kirchmann criticizes studies that show insignificant differences between organic farming and conventional farming. In Sweden, crop production requires $50 \%$ more arable land, as yields are 35\% lower (Kirchmann, 2019).

Konstantinidis criticizes the EU's policy of supporting organic farming and wonders if it focuses on national "repeasantization". In the context of the CAP, there are objectives related to supporting small farms in organic farming and their role in employment, promoting local knowledge. In contrast, the EU organic farms are larger than conventional ones and require less labour, they have high mechanization and monoculture production (Konstantinidis, 2018).

The proportion of organic areas is correlated with the average size of the farms; the share of organic farming is not related to the higher utilization of agricultural labour per hectare. The results of the study raise the question of conventionalization of the organic farming and adherence to the ideas and principles of organic farming (Konstantinidis, 2016). 
Publications emphasize the need to modernize the organic farming sector, taking into account the principles of the circular economy and applying innovation (Zanoli et al., 2019), making organic farming sustainable, result-based, continuously adaptive, and site-oriented (Niggli et al., 2017; Arbenz et al., 2017).

However, the social aspects of the organic farming are generally little included in the assessments.

The production of organic products also depends largely on consumer values. Creating sustainable consumption values can contribute to increasing demand for organic produce (Schosler et al., 2013). Scientific publications deal with the ethical side of organic production. The individual and the public must be in balance when creating a new eco-habitus (Schrank \& Running, 2018).

Organic farms plays an important role in the local food systems (LFSs) as demand for spatially recognized produce increases. (Papaoikonomou \& Ginieis, 2017). This is where local food communities are formed.

In conclusion, there is no clear view of the role of the organic farming in rural development. Still, the contribution of organic farming goes beyond the traditional values of selected economic indicators.

\section{Development of organic farms in Latvia and Baltic States}

A number of organic farms rapidly increased in Latvia after joining the EU and introduction of Organic farm (OF) support in 2004 - 2006. The largest number of organic farms could be observed in 2008, while a number of these farms significantly reduced within next three years. These changes may be linked to completion of 5-year obligation period assumed based on RDP 2004-2006, after which a portion of farms chose not to continue obligations in the new period. In turn, since 2015, starting the obligations of the new RDP 2014-2020 period, more than 1200 OF were registered within 2 years, which formed $35 \%$ of their total number in 2014.

Territorial layout of the OF in the regions of Latvia is not even. A significantly larger number of OF is located in Latgale and Vidzeme regions, while it is significantly smaller in other regions (Figure 1).

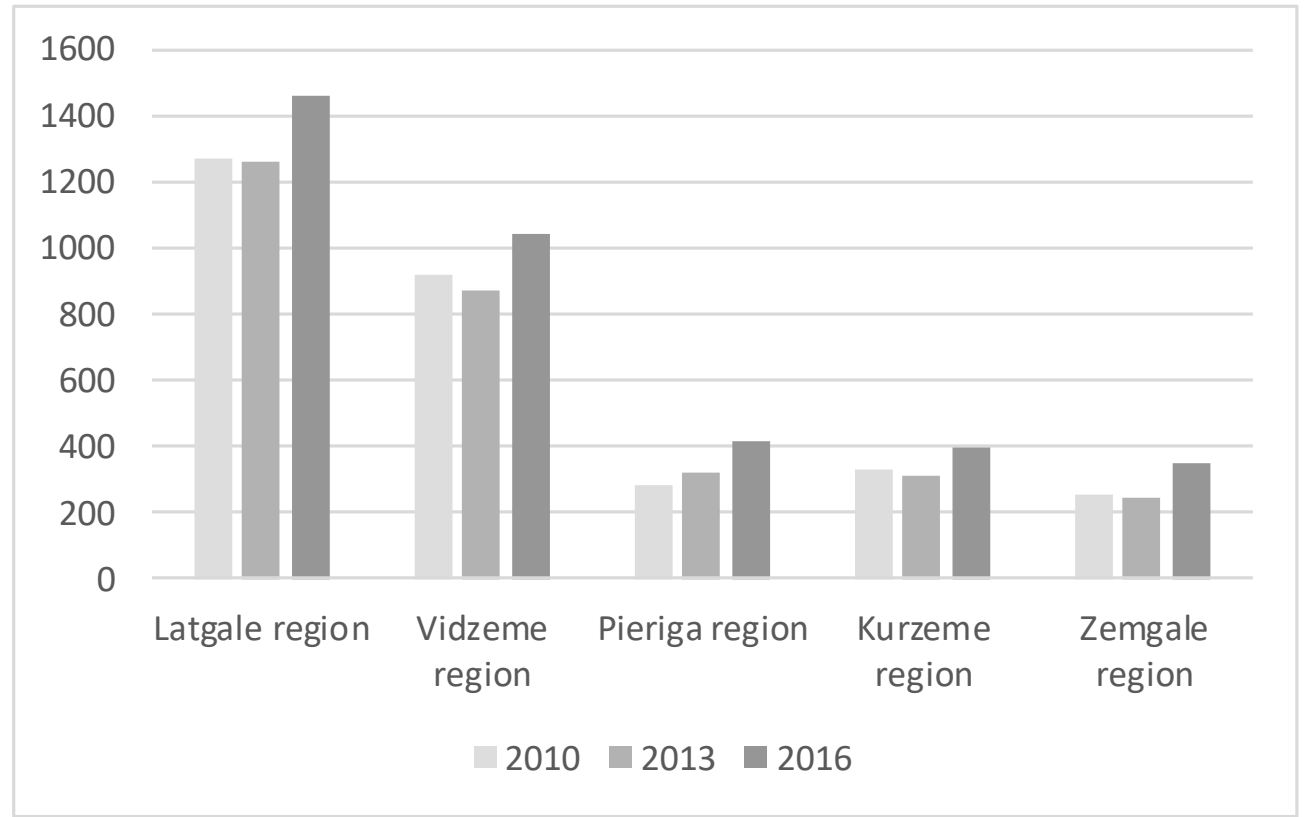

Source: Author's calculation based on Latvian Central Statistical Bureau data

Fig. 1 A number and dynamics of organic farms in the regions of Latvia 
It should, however, be rated positively that the most rapid increase in a number of such farms during the period between 2010 and 2016 was in the regions of Pieriga (by $43 \%$ ) and Zemgale (37\%) regions, where this number before than was the smallest. The largest proportion of OF in the total number of all farms was maintained in the Vidzeme region - $7.5 \%$, followed by the Latgale region with $6.1 \%$, and the smallest proportion is still observed in the Zemgale region - $3 \%$ (2016). We can conclude that organic farms concentrate in regions and areas with less favourable soil and climatic conditions.

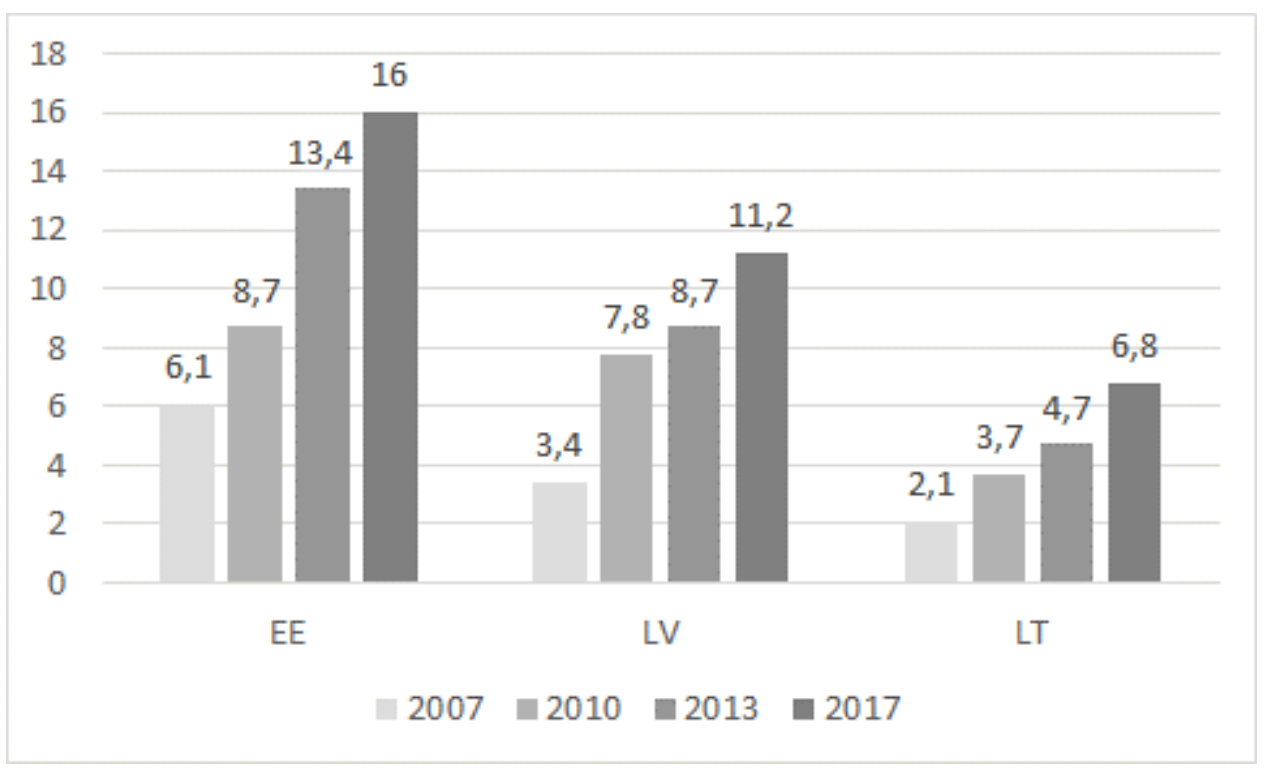

Source: Eurostat

Fig. 2 Share of organic area in the total UAA in the Baltic States from 2007 to 2017

Assessing the total volume of the areas of organic farming, they are larger in Latvia compared to other Baltic States. Proportion of organic areas in the total UAA during the entire period from 2007 to 2017 was the highest in Estonia, but the lowest in Lithuania (Figure 2.), while the increase trend in all Baltic States is approximately similar.

\section{Economic indicators of organic farms in Latvia}

Economics of organic farms is characterized by value of the produce and costs per 1 ha.

We may understand the economic return of manufacturing by comparing value and costs of the produce. Value of the produce is the assessment of all manufactured produce in cash according to accounting data (both sold and self-produced items, but not including any subsidies and state support). Costs of goods and services necessary for the manufacturing process are understood as the costs. The Farm Accountancy Data Network distinguishes three types of costs: 1 ) intermediary consumption - costs of the goods and services used in the manufacturing process; 2) depreciation of fixed assets; 3 ) external costs - they include costs of the hired workforce, land rental payments, as well as the costs of the borrowed capital. In this paper, we assess the total amount of all these costs.

Taking into account that the produce value and costs significantly depend on the selected specialization, these indicators are viewed in the main specialization groups, represented in the organic farms (Figure 3).

Data show that the land areas per produce unit in OF are larger than in the conventional farms. In addition, in the farms with grazing livestock, the respective difference is the smallest (30\%), while in the farms of mixed specialization it reaches even 3 times. Yet, the costs per area unit are 
also much higher in the conventional farms, except for the farms with grazing livestock, where the difference is only $8 \%$. It is related to smaller expenses for fertilizer and plant protection, lesser processing of soil, as well as less intensive farming in general.

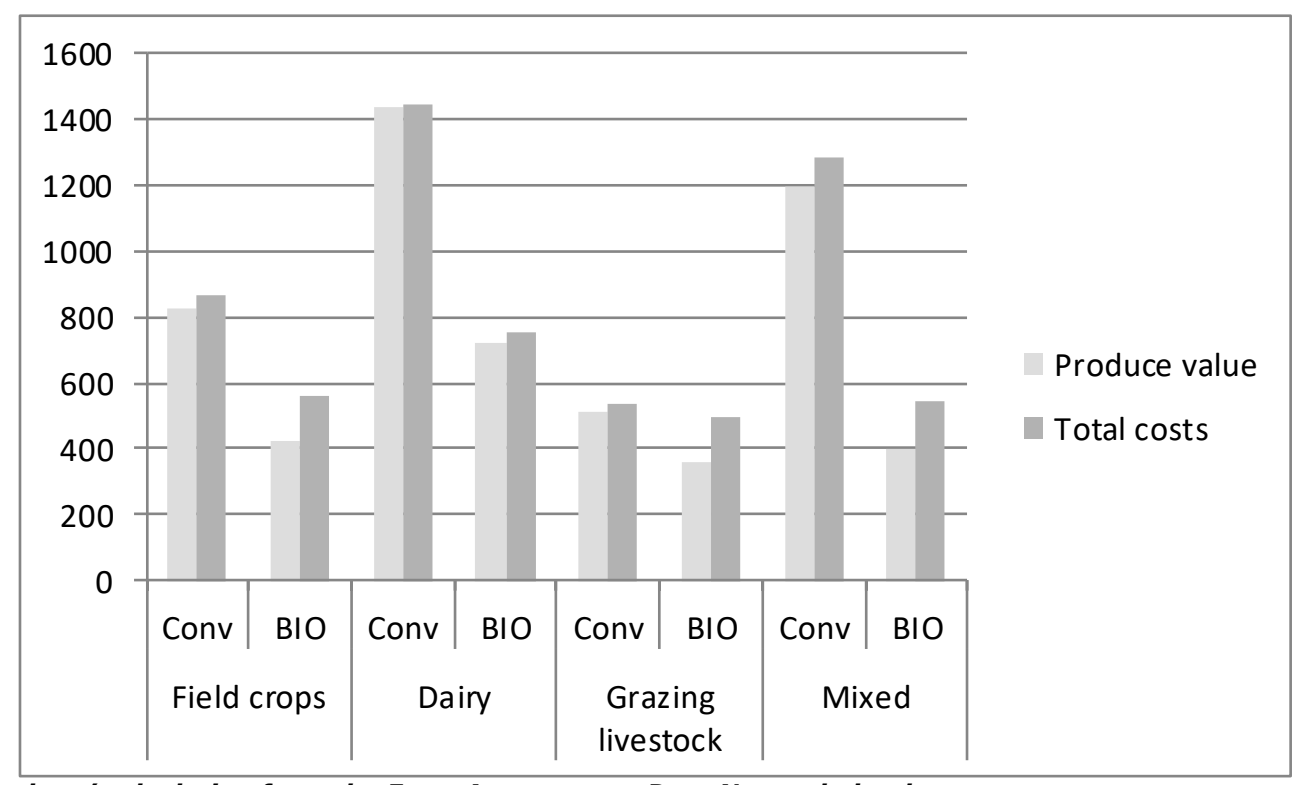

Source: Authors' calculation from the Farm Accountancy Data Network database

Fig. 3 Value and costs of the produce (EUR/ha) in organic and conventional farms in 2017

Thus, the amount of the total costs in the viewed specializations in the organic farms and conventional farms in average exceeds the value of the produce, yet this excess is varying. The largest negative difference in absolute numbers is formed in the farms with grazing livestock 115 EUR/ha, which may formally be covered by means of additional compensation. The second largest difference is observed in field crop farms - $93 \mathrm{EUR} / \mathrm{ha}$. The difference in the mixedspecialization farms is smaller - in average of $49 \mathrm{EUR} / \mathrm{ha}$, while it is the smallest in the dairy farming - only 12 EUR/ha. It should be noted that due to comparatively small sample of the Farm Accountancy Data Network, the aforementioned data shall be considered as indicative only and require more detailed assessment. The field representatives explain such differences with the fact that a majority of the dairy farms are operating already for an extended period, thus, their costs have stabilized. Many new farms have started their operation in the field of grazing livestock in the recent years, thus, their costs are comparatively greater compared to obtained produce.

The data on productivity and obtaining produce in general shows that the productivity and value of produce per area unit of the organic crops in the crop production of Latvia is significantly lower than in the conventional farms. It is assumed in the studies performed in Europe that productivity of organic crops is approximately by $20 \%$ lower than in the conventional farms (Paragraphs 4.1). Similar results - 20-25\% are acquired in Latvia by comparing the most popular crops, except for wheat where the difference is much higher. Less intense crop rotation (with a greater proportion of grassland) is applied in organic farms, thus, the average value of produce to be acquired from the land area is significantly lower. Taking into account that the produce value and costs significantly depend on the selected specialization, these indicators are viewed in the main specialization groups, represented in the organic farms.

The produce value and costs depend also on the UAA in management of the farm. As shown by the data summary of the Farm Accountancy Data Network in 2017, the most effective use of land in terms of area is in the smallest farms (up to $30 \mathrm{ha}$ ). The value of the produce manufactured therein 
from 1 ha was EUR 977, which is almost 3 times more than in the group of the largest farms (with UAA over 250 ha) (Figure 4).

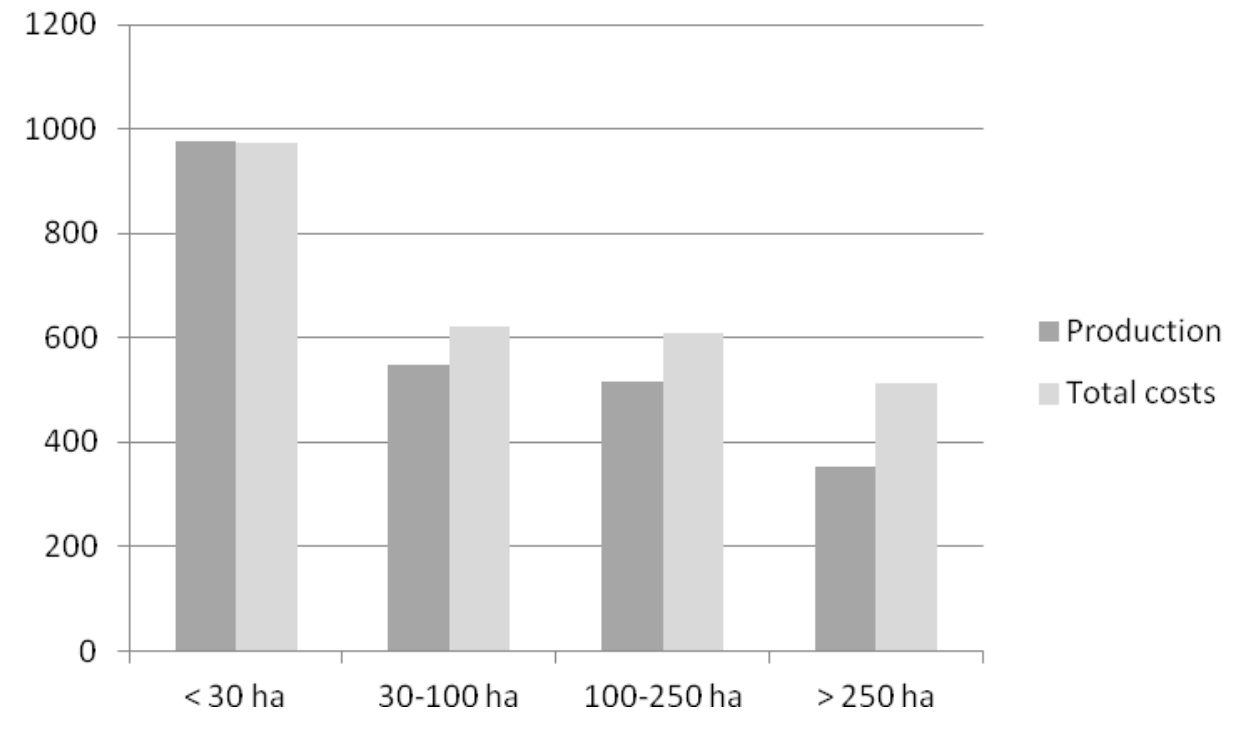

Source: Authors' calculation from the Farm Accountancy Data Network database

Fig. 4 Value and total costs of OF produce (EUR/1 ha UAA) in breakdown by UAA in 2017

The highest level of costs per 1 ha ( 975 ha) is observed in the smallest farms in terms of area; yet, they form the only group, for which the value of the produce covers the costs. Majority of these farms are engaged in the dairy farming, as well as they have mixed specialization. Some farms are engaged in the field of pig farming and poultry farming, which significantly increases the average produce value, but even without this specialization, for the group's farms, it is higher than in other groups.

In turn, the largest farms in terms of areas make the least volume of produce per 1 ha UAA, and they have the greatest negative difference between revenue and expenditure. The farms of this group are engaged mostly in breeding of grazing livestock and arable farming. In terms of economics, they belong to the group of medium-large and large farms - standard output is mostly within the range of EUR 50,000 and 200,000.

\section{Conclusions, proposals, recommendations}

1) Scientific publications do not reach clear conclusions about the economic, social and environmental benefits of organic farming. Opinions and arguments differ based on different research approaches, initial assumptions, methods chosen.

2) Nevertheless, the contribution of organic farming goes beyond the traditional values of selected economic indicators. In addition, as an initially marginal niche product, organic farming changes conventional agrotechnical approaches to production, making them more environmentally and human friendly.

3) Organic farming in Latvia has become a significant type of farming, and a lower produce value compared to costs is acquired therein, thus additional support is important for this type of farming.

4) Organic farms concentrate in regions and areas with less favourable soil and climatic conditions, what reduces their contribution to environmental goals.

5) A limiting factor for the development of organic farming so far was a limitation for the new farms to apply for the support measures. 
6) Upon increase of area for one organic farm, the value of the obtained produce from ha reduces, as well as a negative difference between the produce value and costs increases. Thus, it is rational to recommend the facilitation of formation of a greater number of organic farms, while limiting increase of the areas managed by one farm.

\section{Bibliography}

1. Arbenz, M., Gould, D., Stopes, C., 2017. ORGANIC 3.0-the Vision of the Global Organic Movement and the Need for Scientific Support. Org. Agr. 7:199-207

2. Crowder, D. W. \& Reganold, J. P. Financial Competitiveness of Organic Agriculture on a Global Scale. Proc. Natl Acad. Sci. USA 112, 7611-7616 (2015

3. Kirchmann, H. 2019. Why Organic Farming is not the Way Forward. Outlook on Agriculture Vol. 48(1) 22-27

4. Konstantinidis, C., 2016. Assessing the Socio-economic Dimensions of the Rise of Organic Farming in the European Union, Review of Social Economy, 74:2, 172-193

5. Konstantinidis, C., 2018. Capitalism in Green Disguise: The Political Economy of Organic Farming in the European Union. Review of Radical Political Economics. Vol. 50(4) 830-852 Union for Radical Political Economics

6. Lorenz, K. Lal, R. 2016. Environmental Impact of Organic Agriculture. Advances in Agronomy. ISSN 00652113.Elsevier Inc.http://dx.doi.org/10.1016/bs.agron.2016.05.003

7. Melece, L., 2010. Environmentally Friendly Agriculture: Development issues in Latvia. Socialiniai Tyrimai/ Social research. $\mathrm{Nr} 2(19), 37-46$

8. Melece, L., Shena, I., 2019. Development Issues of Organic Farming in Latvia, SGEM 2019, Conference proceedings, Vol. 19, Issue: 5.3

9. Niggli, U., Andres, Ch., Willer, H., Baker, B.P., 2017. Building a Global Platform for Organic Farming Research, Innovation and Technology Transfer, Org. Agr. 7:209-224

10. Papaoikonomou, E., Ginieis, M., 2017 Putting the Farmer's Face on Food: Governance and the ProducerConsumer Relationship in Local Food Systems. Agric Hum Values 34:53-67

11. Ponisio LC, M'Gonigle LK, Mace KC, Palomino J, de Valpine P, Kremen C. 2015. Diversification Practices Reduce Organic to Conventional Yield Gap. Proc. R. Soc. B 282: 20141396. http://dx.doi.org/10.1098/rspb.2014.1396

12. Reganold, J.P., Wachter, J.M., 2016. Organic Agriculture in the Twenty-first Century, Nature Plants. Vol 2. www.nature.com/natureplants

13. Rios, I. et al. 2016. Redefining Rural Prosperity Through Social Learning in the Cooperative Sector: 25 years of Experience from Organic Agriculture in Spain, Land Use Policy 54, 85-94

14. Rivera M. et al., 2017. Rethinking the Connections between Agricultural Change and Rural Prosperity: A Discussion of Insights Derived from Case Studies in Seven Countries. Journal of Rural Studies.

15. Schosler, H., Boer, J., Boersema, J.J., 2013. The Organic Food Philosophy: A Qualitative Exploration of the Practices, Values, and Beliefs of Dutch Organic Consumers Within a Cultural-Historical Frame. Agric Environ Ethics 26:439-460

16.Schrank, Z., Running, K., 2018. Individualist and Collectivist Consumer Motivations in Local Organic Food Markets Journal of Consumer Culture Vol. 18(1) 184-201

17. Sumane, S., 2010. Lauku inovacija: jaunu attistibas praksu veidosana. Biologiskas lauksaimniecibas piemers. (Rural Innovation: Creation of New Development Practices. Example of Organic Farming). Promotional Paper, LU

18. Zanoli, R., Migliorini, P, Canali, S, Cicia, G., 2019. Special Issue: 'Organic Farming and Agroecology as a Response to Global Challenges'-selected papers from the 2nd International GRAB-IT Workshop (GRAB-IT 2018), Anacapri, Italy, 26-27 June 2018, Org. Agr. 9:457-458 